\title{
Terrestrial heat flow in areas of dynamic influence of faults in the Baikal rift zone
}

\author{
S. V. Lysak and S. I. Sherman \\ Institute of the Earth's Crust, Siberian Branch of Russian Academy of Sciences, Lermontov Street 128, Irkutsk, 664033 , \\ Russia
}

Received: 5 October 2000 - Revised: 19 December 2001 - Accepted: 5 February 2002

\begin{abstract}
Terrestrial heat flow in the Baikal rift zone is irregularly distributed. Its high values are associated with active faults and areas of dynamic influence of faults. Stress patterns in these regions have been studied across and along major faults. Measurement sites under consideration are those located not farther than $30 \mathrm{~km}$ from the given fault axis. Across the fault strike, heat flow values are revealed to decrease with distance from the fault axis. Along the fault strike, variations of heat flow values are within measurement errors, with the exception of thermal spring sites. It is established that heat flow values are regularly changeable. Similar relationships are obtained for heat flow patterns in other continental rift zones.
\end{abstract}

\section{Introduction}

Heat flow acting from the Earth's interiors is one of the primary factors determining geodynamic activity of geological structures and activity of faults. We discuss quantitative relationships between heat flow values and their variations across and along fault zones using data from the Baikal rift zone (BRZ) and the territory of the Siberian and Transbaikalian microplates (Fig. 1) in the eastern part of the Eurasian continent. The variability of these values is calculated as sums of squares of deviations from the overall average values and double estimation error $(2 \sigma)$; average values of heat flow and density of the faults are obtained.

Heat flow stations are primarily concentrated in the central part of the Baikal rift zone (BRZ), especially within and around Lake Baikal as well as in some other southern regions of the Siberian microplate (Fig. 2). The database of the given heat-flow map includes data received from the on-land area and within the Lake Baikal, from geothermal surveys con-

Correspondence to: S. I. Sherman

(ssherman@earth.crust.irk.ru) ducted in exploratory drillholes ranging from 0.3 to $3-5 \mathrm{~km}$ in depth $(0.3$ to $1 \mathrm{~km}$ in ridges, 1 to $2.5 \mathrm{~km}$ in intermountain depressions, and 2.5 to $5 \mathrm{~km}$ on the Siberian microplate) and from 0.5 to $2 \mathrm{~km}$ (mostly $<1 \mathrm{~km}$ ) at altitudes above sea level. Precise heat flow measurements were carried out for several weeks or several months (occasionally up to 5 years) after drilling had been complete. Results of hydrogeological and cryological studies were also used in constructing the map (Lysak, 1978; 1984; 1995).

Marine studies at transversal profiles across Lake Baikal were carried out by oceanographic techniques from aboard of a scientific vessel. Either a thermal gradiometer (Duchkov et al., 1987) or a cable thermistor probe penetrating through $1 \mathrm{~m}$ to $3 \mathrm{~m}$ thickness of bottom sediments were used (Golubev, 1982; Golubev et al., 1993).

An average heat flow value of Lake Baikal basin is $78 \pm 36 \mathrm{~mW} / \mathrm{m}^{2}$. In other rift depressions (Tunka, Barguzin), it is $62 \pm 13 \mathrm{~mW} / \mathrm{m}^{2}$. Thermal waters of these intermountain artesian basins are distinguished in the thermal field as regional anomalies. Their local high values exceed 80 $100 \mathrm{~mW} / \mathrm{m}^{2}$ in the fault zones bordering these depressions. At the north-eastern flank of the BRZ, heat flow drops down to $50 \mathrm{~mW} / \mathrm{m}^{2}$ and below; it can reach $70-80 \mathrm{~mW} / \mathrm{m}^{2}$ only at some local fault sections (see Fig. 2). The regional heat flow of ridges bordering the rift depressions is $40 \pm 6 \mathrm{~mW} / \mathrm{m}^{2}$.

An average regional heat flow of the Transbaikalian microplate is $52 \pm 11 \mathrm{~mW} / \mathrm{m}^{2}$. In the southern Siberian microplate, an average heat flow value is around $38 \pm 8 \mathrm{~mW} / \mathrm{m}^{2}$. Low values are observed at the marginal uplifts (Lysak, 1988).

Faults in the BRZ are numerous. A fault map of Fig. 3 shows fault directions, genetic types and ages (Sherman et al., 1992). In the BRZ central part, the $60^{\circ}$ trending faults dominate; they follow the general strike of the rift zone. The north-west-trending faults are observed perpendicular to the rift zone strike. In the BRZ south-western part, sub- 


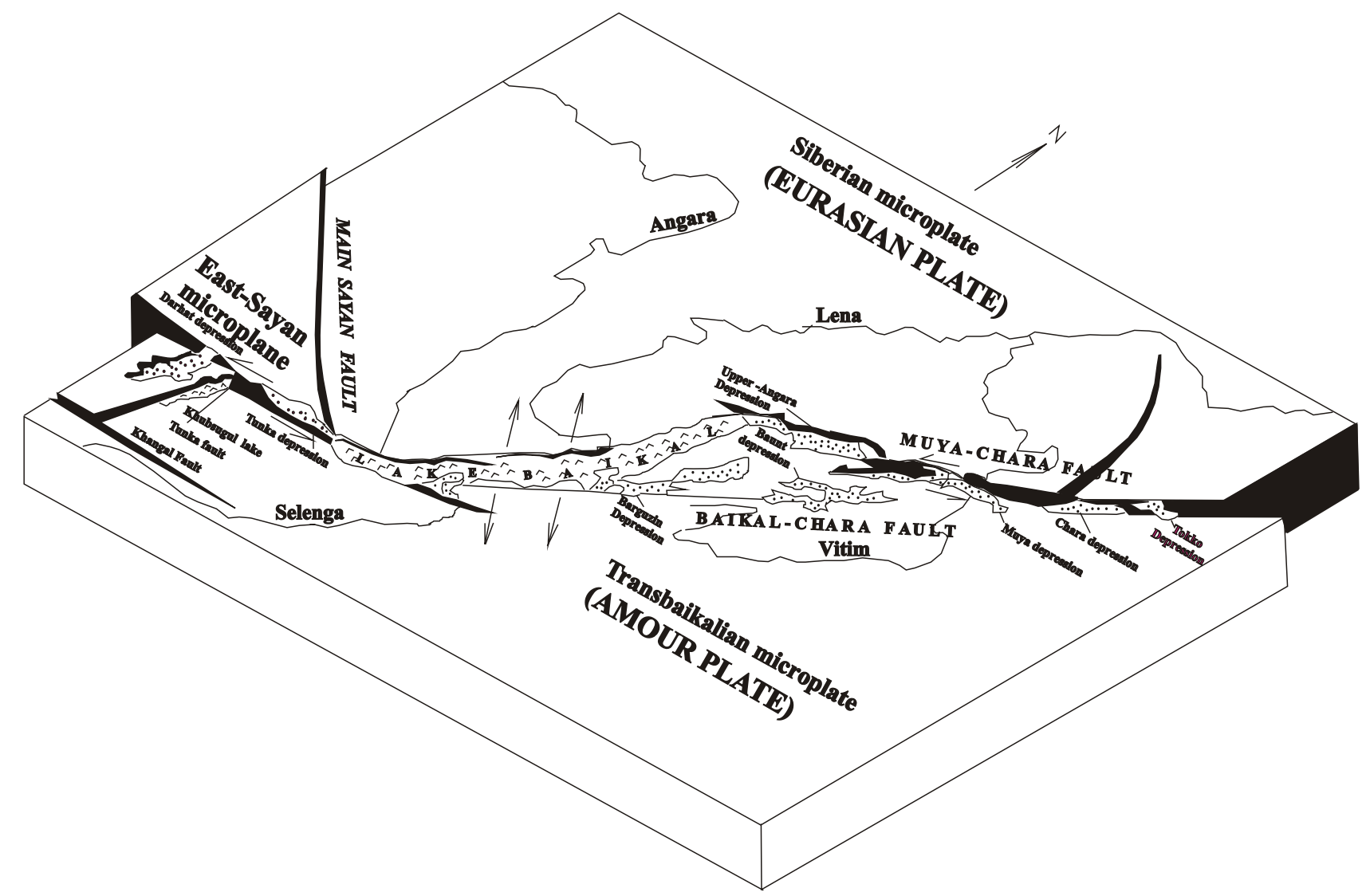

Fig. 1. Block-scheme the Baikal rift zone formation. Scale 1:5000 000 (Sherman and Levi, 1977, with additions).

latitudinal and latitudinal faults are predominant. Transcurrent or meridional faults are less abundant. The $45^{\circ}$ trending faults predominate in the north-eastern part of the BRZ. Their trends do not coincide with the general rift zone strike. Latitudinal faults are second in number, whereas longitudinal ones are even rarer.

The BRZ central part is characterized by a maximum number of the Cenozoic faults trending in agreement with the BRZ general strike. At the BRZ flanks, the predominant fault trend coincides with the strike of the most extensive deepseated faults of the basement; these faults are pre-Cenozoic in age (Sherman et al., 1992; Levi and Sherman, 1995).

A non-uniform distribution of faults and heat flow values is evident in the BRZ and its adjacent territory. Nonetheless, some quantitative relationships between faults and heat flow can be revealed.

\section{Distribution of heat flow in fault zones}

Numerous active faults are revealed at the bottom of Lake Baikal (Fig. 4). An average heat flow value of this area is $78 \pm 36 \mathrm{~mW} / \mathrm{m}^{2}$. In fault zones, it reaches $87 \pm 10 \mathrm{~mW} / \mathrm{m}^{2}$. There are local sites where the submarine heat flow exceeds $200-1000 \mathrm{~mW} / \mathrm{m}^{2}$. Extremely high values of heat flow over $6000-8000 \mathrm{~mW} / \mathrm{m}^{2}$ are associated with submarine hydrothermal vents in active fault zones (Golubev et al., 1993); however, these high values were not taken into consideration when the average heat flow value was estimated.

In deep bottom depressions and at underwater uplifts and blocks, an average heat flow value is by 1.5 times lower ( $69 \pm 23$ and $65 \pm 18 \mathrm{~mW} / \mathrm{m}^{2}$, accordingly).

At the Transbaikalian microplate, an average heat flow value of fault zones is $71 \pm 3 \mathrm{~mW} / \mathrm{m}^{2}$. In intermountain depressions and at ridges and uplifts, average heat flow values of fault zones are $52 \pm 9$ and $47 \pm 9 \mathrm{~mW} / \mathrm{m}^{2}$, accordingly. Even in the southern part of the Siberian microplate, heat flow in fault zones is higher than that in the adjacent areas.

The above regularity is typical of other rift zones, such as the Basin-and-Range Province, the Rio Grande rift, the Rhine and Rhone rifts, the East African rift system and surrounding areas (Table 1).

Thus, high values of terrestrial heat flow are more characteristic of fault zones and, especially, of zones of active faults in rift depressions, rather than of the surrounding areas.

\section{Heat flow and density of faults}

Density of faults, $d_{f}$ is a number of faults, $n$ within an area of $\sim 5 \times 10^{3} \mathrm{~km}^{2}$. It is calculated from field data and information from geological maps (Sherman et al., 1992). A map of density of faults in the Baikal rift zone is shown in Fig. 3b. 


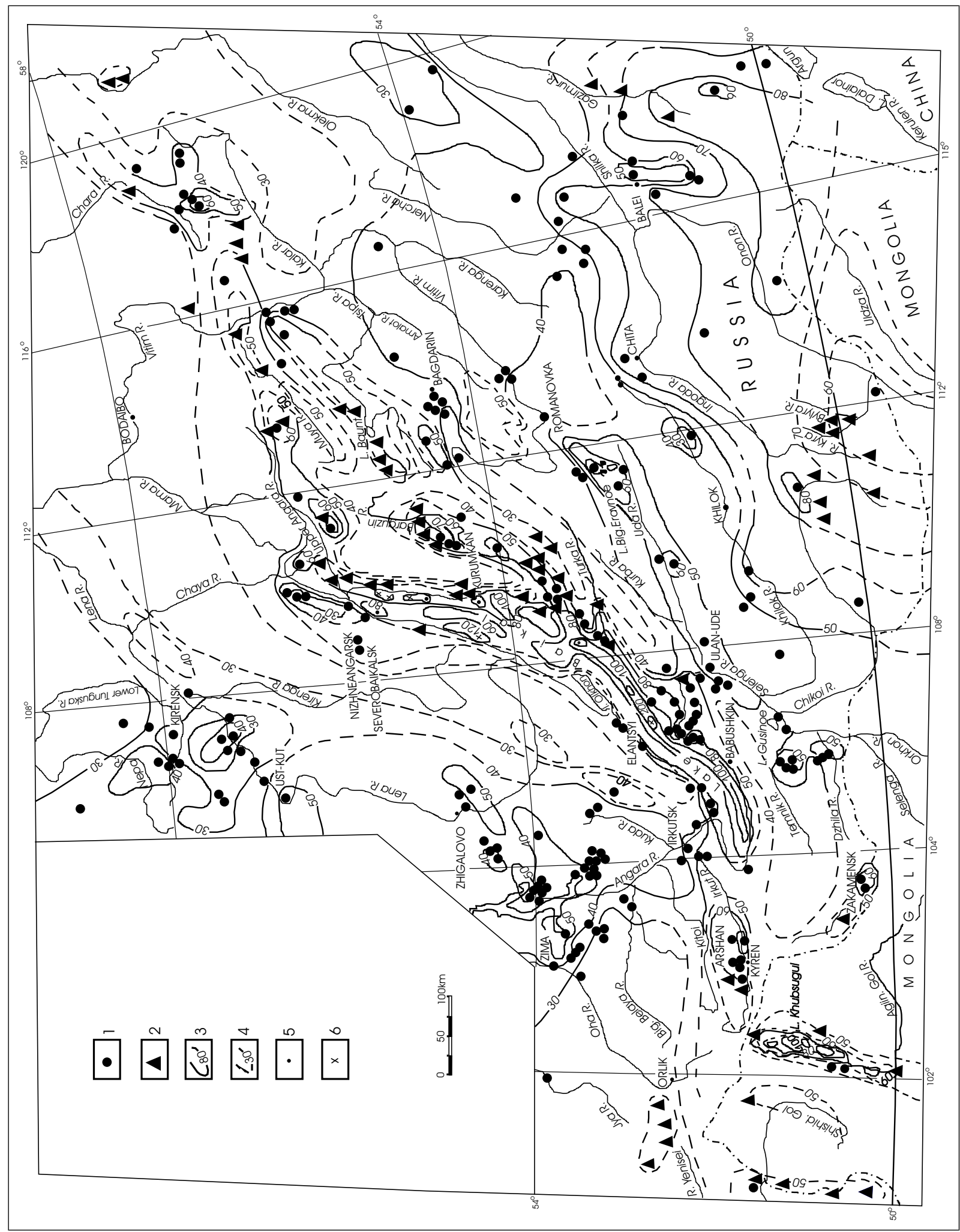




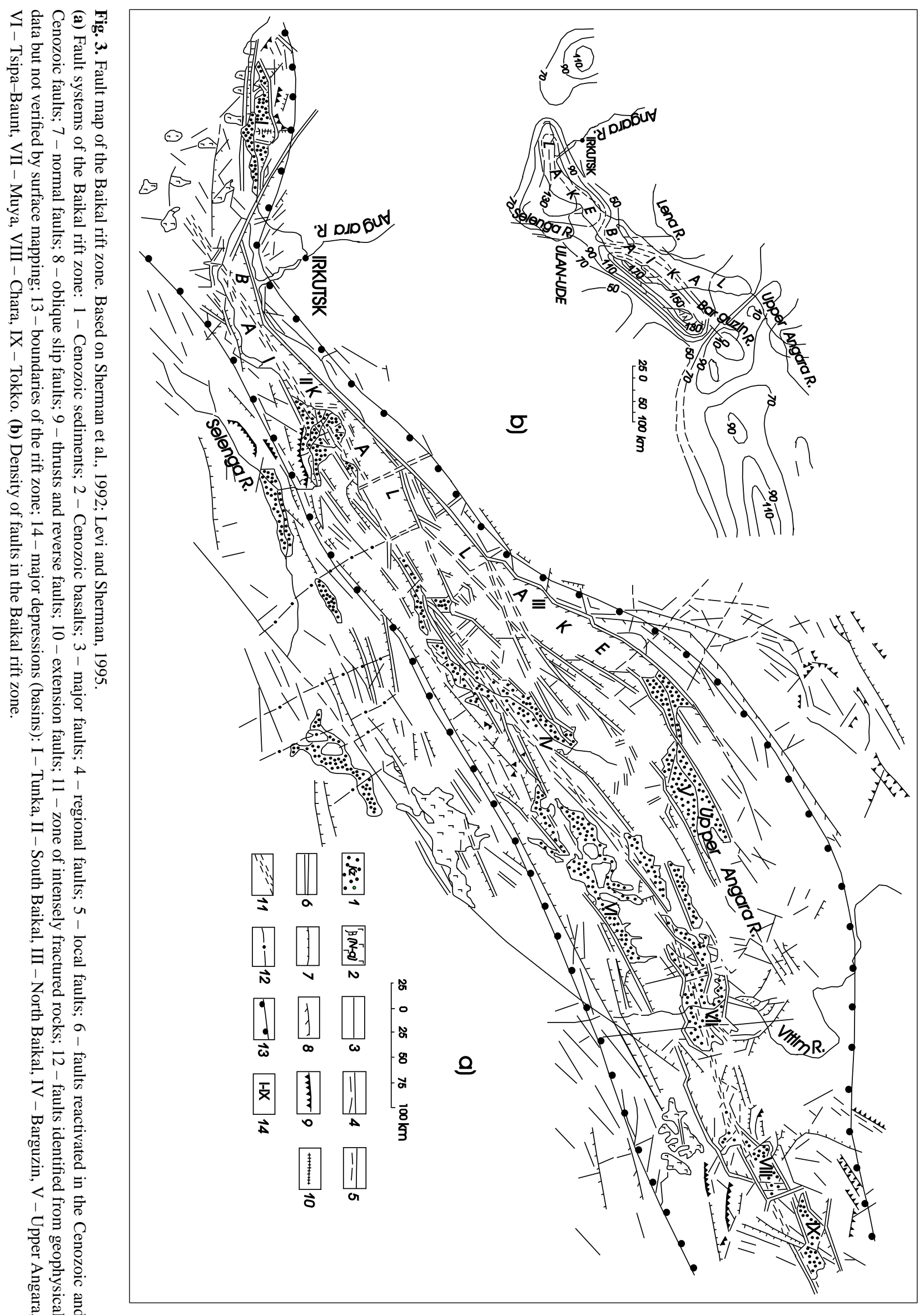


Table 1. Number of heat flow data $(\mathrm{N})$, average value of heat flow $\left(\mathrm{q}, \mathrm{mW} / \mathrm{m}^{2}\right)$ and redoubled error of average heat flow estimate $(2 \sigma)$ in the fault zones of continental rifts and surrounding areas (Lysak, 1999)

\begin{tabular}{|c|c|c|c|c|c|c|c|c|c|c|}
\hline \multirow[t]{2}{*}{ Regions } & \multicolumn{2}{|c|}{ Areas of faults } & \multicolumn{2}{|c|}{$\begin{array}{l}\text { Rift depressions } \\
\text { uplifts }\end{array}$} & \multicolumn{2}{|c|}{ Interdepression } & \multicolumn{2}{|c|}{ Rift "shoulders" } & \multicolumn{2}{|c|}{ Surrounding areas } \\
\hline & $\mathrm{N}$ & $\mathrm{q} \pm 2 \sigma$ & $\mathrm{N}$ & $\mathrm{q} \pm 2 \sigma$ & $\mathrm{N}$ & $\mathrm{q} \pm 2 \sigma$ & $\mathrm{N}$ & $\mathrm{q} \pm 2 \sigma$ & $\mathrm{N}$ & $q \pm 2 \sigma$ \\
\hline \multicolumn{11}{|c|}{ Cenozoic continental rifts } \\
\hline $\begin{array}{l}\text { Cordillera rift } \\
\text { system: Basin-and- } \\
\text { Range Province, } \\
\text { Plato Colorado } \\
\text { North and Rio } \\
\text { Grande rift; } \\
\text { North America }\end{array}$ & 48 & $161 \pm 86$ & 87 & $91 \pm 35$ & 62 & $94 \pm 26$ & 86 & $72 \pm 29$ & 68 & $57 \pm 17$ \\
\hline $\begin{array}{l}\text { Rhine-Lybian rift } \\
\text { belt: Rhine, Rhone } \\
\text { and African-Sicilian } \\
\text { rift zones; } \\
\text { Western and Central } \\
\text { Europe }\end{array}$ & 90 & $107 \pm 34$ & 72 & $96 \pm 33$ & 5 & $70 \pm 6$ & 81 & $83 \pm 22$ & 225 & $74 \pm 23$ \\
\hline $\begin{array}{l}\text { East African rift } \\
\text { system: Dead Sea } \\
\text { rift, Ethiopia and } \\
\text { Kenya rift zones; } \\
\text { Central and South } \\
\text { Africa }\end{array}$ & 20 & $102 \pm 39$ & 93 & $60 \pm 30$ & 5 & $105 \pm 43$ & 60 & $54 \pm 22$ & 62 & $58 \pm 28$ \\
\hline $\begin{array}{l}\text { Baikal rift zone: } \\
\text { Baikal, Tunka, } \\
\text { Barguzin, Upper } \\
\text { Angara, Myua rifts; } \\
\text { Transbaikalia }\end{array}$ & 76 & $109 \pm 39$ & 380 & $78 \pm 36$ & 72 & $69 \pm 35$ & 76 & $56 \pm 19$ & 57 & $52 \pm 11$ \\
\hline \multicolumn{11}{|c|}{ Mesozoic and Paleozoic continental rifts } \\
\hline $\begin{array}{l}\text { Oslo, North Sea; } \\
\text { Kamerun and Niger } \\
\text { rifts }\end{array}$ & 13 & $84 \pm 16$ & 13 & $68 \pm 18$ & 14 & $58 \pm 12$ & 24 & $59 \pm 14$ & & \\
\hline West Africa & & & & & & & & & 146 & $57 \pm 20$ \\
\hline
\end{tabular}

An average density of faults is $100 \pm 27$ in the Lake Baikal basin, $70 \pm 24$ in other rift depressions, $62 \pm 22$ at rift "shoulders" (all values obtained within areas of $5 \times 10^{3} \mathrm{~km}^{2}$ ). The density of faults is also high in the Transbaikalian microplate: $65 \pm 17$ in depressions, $70 \pm 30$ at ridges and uplifts. The southern part of the Siberian microplate is characterized by low densities of faults: $15 \pm 4$ in depressions, $19 \pm 6$ at uplifts.

The highest density of faults is observed at the axial part of the Baikal rift zone, wherein local anomalies are characterized by double and even higher values of fault density. This area is characterized by high regional heat flow, local heat flow anomalies and hot spring occurrence (see Figs. 2, 4a).

A comparison of values of fault density and heat flow allows us to reveal a regularity: heat flow is higher in the areas of higher density of faults. This regularity is characteristic not only of rift zones, but also of the surrounding ar- eas and major geological structures. It is rather strong and can be revealed even in the regions of relatively low geodynamic activity. For example, at the Transbaikalian microplate, wherein an average density of faults is about 70 , an average heat flow is $52 \mathrm{~mW} / \mathrm{m}^{2}$. In the southern areas of the Siberian microplate, the density of faults is less than 20 , an average heat flow is about $40 \mathrm{~mW} / \mathrm{m}^{2}$.

The available data base has been computer processed by a linear binary correlation between values of heat flow and density of faults; correlation factor $\mathbf{r}$ and its error range are defined for different structures. This allows us to establish an relation between two values under analysis, $q$ and $d_{f}$. Then, it is possible to obtain a regression equation of this relation (see below).

Results of the binary correlation between the values of heat flow and density of faults show a non-stable relationship be- 


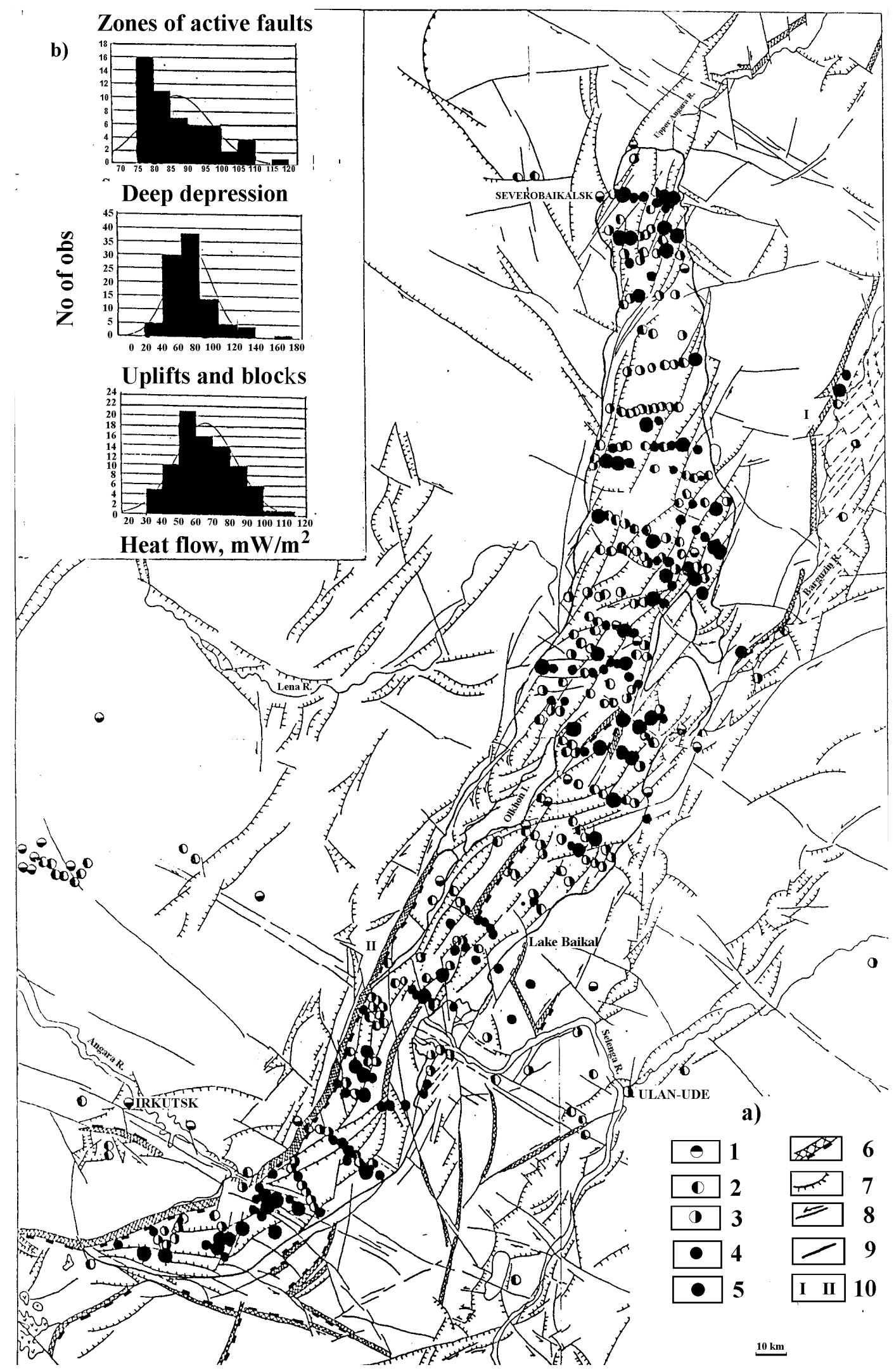

Fig. 4. Terrestrial heat flow and major active faults of the Lake Baikal rift depression. Based on Golubev et al., 1993; Lysak, 1995; Levi et al., 1997. Heat flow values:

$1-<40 ; 2-40-59 ; 3-60-79 ; 4-80-99 ; 5->100 \mathrm{~mW} / \mathrm{m}^{2}$. Major active faults: $6-$ faults with estimated thickness of zones of tectonic dislocation; 7 - normal faults; 8 - strike-slip faults; 9 - faults with undetermined type of movements; 10 - areas of dynamic influence of Barguzinsky fault (I) and Primorsky fault (II). 
tween these geodynamic parameters, with considerable variations of correlation factors, $\mathbf{r}=0.7 \pm 0.5$ in the BRZ and $\mathbf{r}$ $=0.8 \pm 0.6$ in Lake Baikal itself. At the mountain framework of the rift depressions (or rift "shoulders") and at the Transbaikalian microplate, correlation factor $\mathbf{r}$ is $0.6 \pm 0.4$. It is less considerable in the southern part of the Siberian microplate $(\mathbf{r}=0.4 \pm 0.1)$, however the correlation is present there.

Therefore, in the zones of high fault density, heat flow is increased in comparison with that of the other territories. In the BRZ and its adjacent microplates, the fault zones and especially active ones are heated stronger than the areas of mountain ridges and uplifts.

\section{Variations of heat flow values in areas of dynamic in- fluence of faults}

To establish specific relationships between faults and heat flows, a more detailed research has been carried out; the available data on distribution of heat flow across the zones of dynamic influence of faults are analyzed.

Areas of dynamic influence of faults are volumes including the axial zone of the fault and its surrounding zone in three dimensions wherein residual deformations (plastic or fracture) and crush movements are manifested (Sherman et al., 1983).

Qualitative analyses suggest that maximum values of heat flow are typically observed at the fault axial parts (at distance up to $5 \mathrm{~km}$ ). With distance from the fault axis, heat flow decreases gradually. At a distance of $15-25 \mathrm{~km}$, the influence of the given fault does not have any considerable impact on heat flow values, unless it is influenced by any other fault or any other geodynamic factor (fresh faults, modern fissures or others).

For the BRZ, a data base of quantitative estimations of 20 active faults and 150 heat flow values obtained in the areas of dynamic influence of these faults has been analyzed (Lysak and Sherman, 1978). As expected, a reverse dependence of heat flow and the distance between the measurement site and the axial zone of the fault is established. The following regression equation is obtained:

$\mathbf{q}=85.6-2.1 \mathbf{D}\left(\mathrm{mW} / \mathrm{m}^{2}\right)$,

where $\mathbf{q}$ is heat flow in $\mathrm{mW} / \mathrm{m}^{2} ; \mathbf{D}$ is a distance from an axial line of a fault in $\mathrm{km}$.

Unlike the above calculations, the correlation factor is higher and less variable:

$\mathbf{r}=-0.56 \pm 0.17$

For separate faults, $\mathbf{r}$ values and regression equations may be different, but still very similar. For example, at a distance from the Barguzinsky fault to the east ( 8 points of measurements), the equation is the following:

$\mathbf{q}=95-2.8 \mathbf{D}\left(\mathrm{mW} / \mathrm{m}^{2}\right), \quad \mathbf{r}=-0.51 \pm 0.26$.

The western coast of Lake Baikal is characterized by huge geomorphologic rift forms, including faults, though its recent activity is relatively low. The Primorsky fault is located in this area. Variations of heat flow across the strike of its zone of dynamic influence (46 points of measurements) are extremely high:

$\mathbf{q}=84.1-3.2 \mathbf{D}\left(\mathrm{mW} / \mathrm{m}^{2}\right), \quad \mathbf{r}=-0.78 \pm 0.60$.

It can be concluded that across the zones of dynamic influence of relatively active faults, heat flow decreases slower than in the whole adjacent area. For comparison, heat flows and areas of dynamic influence of faults of other continental (the Province of Basins and Ranges, the Rio Grande Rift) and oceanic rifts (the Middle-Atlantic rift) have been analyzed. For example, from 17 heat flow measurements, variations of heat flow across the strike of the San Andreas Fault zone (Henyey and Wasserburg, 1971) are given by the following equation:

$\mathbf{q}=80.2-2.1 \mathbf{D}\left(\mathrm{mW} / \mathrm{m}^{2}\right), \quad \mathbf{r}=-0.60 \pm 0.42$.

It corresponds well to the equation of the average data for active faults in the BRZ (Lysak and Sherman, 1978).

Increased and abnormally high values of heat flow are known in zones of the Rhine-Libyan and Africa-Arabian rift belts, in particular, in the Kenya rift and the Dead Sea rifts (Lysak, 1988, 1992).

\section{Conclusion}

Our research results give grounds for the following conclusions:

1. Heat flow in fault zones is generally higher than that in the adjacent or surrounding areas. It is dependent on a geodynamic regime of the given territory.

2. Heat flow decreases with distance from the fault axis. Lateral geothermal zoning of faults is well agreed with zones of crushing.

Thus, the above described new approach to comparing heat flow and areas of dynamic influence of faults provides the basis for new conclusions and correlation between some of the well known geodynamic parameters. It is especially important for detailed researches of active rift zones and zones of collision, i.e. the areas of active recent destruction of the lithosphere.

Acknowledgements. Special thanks are extended to Dr. D. Delvaux and Prof. A. Khan (IGCP 400 Project leaders) and the Russian Fund of Fundamental Research (grants 00-05-64140; 01-05-97226) for supporting our investigation and our participation in the First Stephan Mueller Conference of the European Geophysical Society held in Israel in 2000. The authors are thankful to Marlies ter Voorde and Jan Safanda, reviewers, for their critical notes and useful advise. 


\section{References}

Duchkov, A. D., Lysak, S. V., and Balobaev, V. T. et al.: Thermal field of Siberian bowels, Nauka, Novosibirsk, 197p. (in Russian), 1987.

Golubev, V. A.: Geothermics of Baikal, Nauka, Novosibirsk, 150p (in Russian), 1982.

Golubev, V. A., Klerkx, J., and Kipler, R.: Heat flow, hydrothermal vents and static stability of discharging thermal water in Lake Baikal (South-Eastern Siberia), Bull.Centres Rech. Explor.-Prod. Elf Aquitaine, 17, 1, 53-65, 1993.

Henyey, T. L. and Wasserburg, G. J.: Heat flow near major strikeslip faults in California, J. Geophys. Res., 76, 32, 7924-7946, 1971.

Levi, K. G., Miroshnichenko, A. I., and San'kov, V. A. et al.: Active faults of the Baikal depression, Bull. Centers Rech. Explor.-Prod. Elf Aquitaine, 21, 399-434, 1997.

Levi, K. G. and Sherman, S. I.: Applied geodynamic analysis. Muse Royal de L'Afrique Centrale - Tervuren, Belgique annales - Sciences Geologiques, 100, 133p, 1995.

Lysak, S. V.: The Baikal rift heat flow, Tectonophysics, 45, 87-93, 1978.

Lysak, S. V.: Terrestrial heat flow in the south of East Siberia,
Tectonophysics, 143, 31-41, 1984.

Lysak, S. V.: Heat flow of Continental Rift Zones, Nauka, Novosibirsk, 200p (in Russian), 1988.

Lysak, S. V.: Heat flow variations in continental rifts, Tectonophysics, 208, 309-323, 1992.

Lysak, S. V.: Terrestrial heat and temperatures in the upper crust in South East Siberia, Bull. Centers Rech. Explore-Prod. Elf Aquitaine, 19, 39-57, 1995.

Lysak, S. V.: Terrestrial heat flow as factor of continental rift geodynamic. Rifting in intracontinental setting: Baikal Rift System and other Continental Rifts, Irkutsk and Lake Baikal, Russia, 122124, 1999.

Lysak, S. V. and Sherman, S. I.: Abyssal heat flow and seismic activity of Pribaikalia. Seismicity and deep structure of Pribaikalia, Nauka, Novosibirsk, 56-68 (in Russian), 1978.

Sherman, S. I., Bornykov, S. A., and Buddo, V. Y.: Areas of dynamic influence of fault, Nauka, Novosibirsk, 112p (in Russian), 1983.

Sherman, S. I. and Levi, K. G.: Transform faults of the Baikal rift zone, Doklady AN SSSR, 233, 2, 454-464 (in Russian), 1977.

Sherman, S. I., Seminsky, K. Zh., and Bornykov, S. A. et al.: Faulting in the lithosphere. Extensional zones, Nauka, Novosibirsk, 228p (in Russian), 1992. 